\title{
Competence assessment algorithm of accounting and economic specialists in the petroleum sector
}

\author{
Dmitriy Khudyakov, Vera Romanyuk* and Maria Ivanova \\ Institute of Natural Resources, National Research Tomsk State University, 36 Lenin Av., Tomsk, \\ 634050, Russia
}

\begin{abstract}
The paper describes the modern competence assessment methodology for economic and accounting specialists in the petroleum sector. The research object is professional competence and assessment approaches. The paper provides the specifications and codifiers developed by the team of contributors.
\end{abstract}

\section{Introduction}

Under rapidly changing market conditions, there is a need for advanced personnel development to ensure the effective activity of any enterprise. The process of advanced personnel development is accompanied by an initial assessment of personnel knowledge and skills. Therefore, some major companies, including those in the petroleum sector could recourse to external organizations [1]. Thus, the research in personnel technical competence development has been carried out within the Department of Natural Resources Economics, National Research Tomsk Polytechnic University for one of the leading oil and gas companies.

\section{Materials and methods}

The following conceptual framework was used:

- Professional competence the willingness and ability to act in accordance with the business requirements, task and problem-solving methodically and independently, as well as self-estimation of one's activities [2];

- Test specification (lat. specificatio listing one's features) a document that provides the targets, objectives, plan and test structure, as well as the basic requirements for testing, result analysis and interpretation [3];

- Codifier a test item structure, which reflects the controlled competence content, item list and need justification [4].

To develop the general competence profile (Table 1), a 4-level competence system (beginning, user, experienced and expert) has been applied.

\footnotetext{
* Corresponding author: romanyukvb@,rambler.ru
} 


\section{Results and discussion}

Work target included (Table 1) initial object analysis based on complied test items for personnel competence assessment. According to the obtained results, follow-up study was carried out and an advanced personnel training program was presented.

Table 1. Competence specialist assessment algorithm.

\begin{tabular}{|c|c|}
\hline \multicolumn{2}{|r|}{ Stage 1 "Object analysis" } \\
\hline $\begin{array}{l}\checkmark \quad \text { study the ro } \\
\checkmark \quad \text { identify the c }\end{array}$ & $\begin{array}{l}\text { of organizational technical units within production process of a } \\
\text { company; } \\
\text { racteristics of relevant personnel knowledge and skills as profiles } \\
\text { and professional competences }\end{array}$ \\
\hline \multicolumn{2}{|r|}{ Stage 2 "Development of test tasks" } \\
\hline $\begin{array}{l}2.1 \text { General } \\
\text { competence profile } \\
\text { formation }\end{array}$ & $\begin{array}{c}\checkmark \text { determine the number of test questions for one specialist } \\
\text { (Table 2); } \\
\checkmark \quad \text { reflect the knowledge and skills requirements for job } \\
\text { position }\end{array}$ \\
\hline 2.2 Codifier formation & $\begin{array}{ll}\checkmark & \text { Present all competence modules; } \\
\checkmark & \text { codifier of test examples (Table } 3 \text { ) }\end{array}$ \\
\hline $\begin{array}{l}2.3 \text { Specification } \\
\text { formation }\end{array}$ & $\begin{array}{c}\text { includes the main characteristics of the test content for each } \\
\text { employee (required competence level, a certain number of } \\
\text { questions for each structural unit, point-rating scoring } \\
\text { system and performance time); } \\
\checkmark \quad \text { test completion time according to job position: heads of } \\
\text { departments - } 120 \text { minutes, for all other professionals -80 } \\
\text { minutes, } \\
\checkmark \quad \text { example of test specifications (Table. 4) }\end{array}$ \\
\hline $\begin{array}{l}2.4 \text { Test item } \\
\text { development }\end{array}$ & $\begin{array}{c}\checkmark \text { multiple choice test including } 4 \text { numbered answer options } \\
\text { from which one or more numbers corresponding to the } \\
\text { correct answer should be chosen [3]; } \\
\checkmark \quad \text { multiple choice ; } \\
\checkmark \quad \text { common test bank (960 test items) }\end{array}$ \\
\hline \multicolumn{2}{|r|}{ Stage 3 "Approbation" } \\
\hline 3.1 Trial testing & $\begin{array}{c}\checkmark \quad \text { submitted report audit on the test task development } \\
\text { involving codifiers and specifications }\end{array}$ \\
\hline $\begin{array}{l}\text { 3.2 Analysis of the } \\
\text { results }\end{array}$ & $\checkmark \quad$ number of questions increased up to 8 in sampling \\
\hline $\begin{array}{l}\text { 3.3 Follow-up } \\
\text { assessment system }\end{array}$ & $\begin{array}{c}\checkmark \quad \text { follow-up assessment system based on obtained analysis } \\
\text { results }\end{array}$ \\
\hline \multicolumn{2}{|r|}{ Stage 4 "Personnel testing" } \\
\hline \multicolumn{2}{|c|}{ Personnel final testing was conducted by the company itself } \\
\hline \multicolumn{2}{|c|}{ Stage 5 "Advanced professional training development" } \\
\hline
\end{tabular}


Due to the obtained test results, the activity plan for advanced professional training was proposed

Table 2. Total number of competence questions [5].

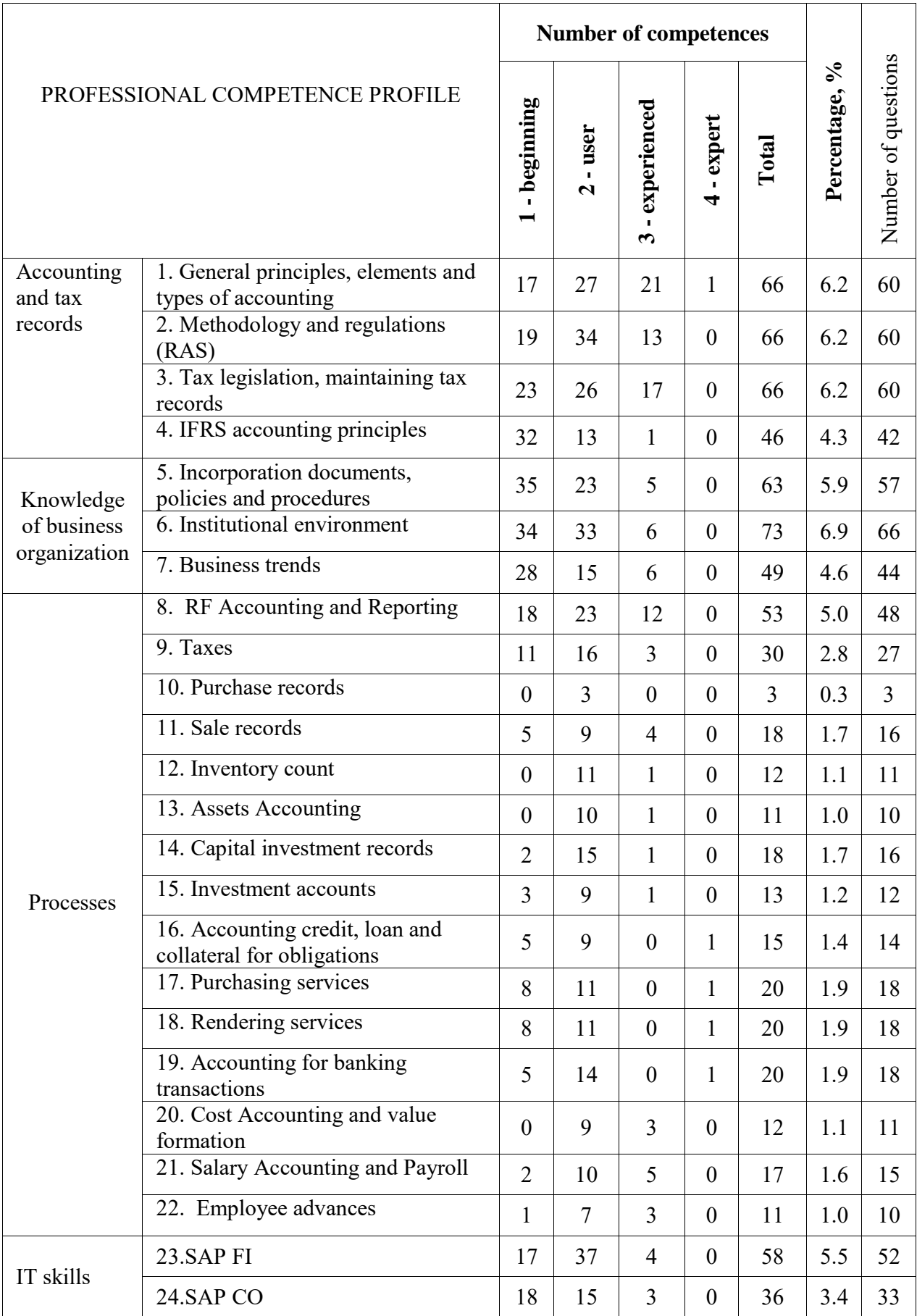




\begin{tabular}{|l|l|c|c|c|c|c|c|c|}
\hline & 25.SAP FI-AA & 6 & 10 & 3 & 0 & 19 & 1.8 & 17 \\
\cline { 2 - 9 } & 26.1C & 14 & 38 & 7 & 0 & 59 & 5.6 & 53 \\
\cline { 2 - 9 } & 27. Electronic archive system & 17 & 21 & 0 & 0 & 38 & 3.6 & 34 \\
\hline 28.MS Office & 6 & 52 & 17 & 0 & 75 & 7.1 & 68 \\
\cline { 2 - 9 } & 29.Lotus Notes & 0 & 0 & 0 & 0 & 0 & 0.0 & 0 \\
\cline { 2 - 9 } & 30.Internet/Intranet & 12 & 53 & 10 & 0 & 75 & 7.1 & 68 \\
\hline Total competences & 346 & 564 & 147 & 5 & 1062 & 100 & 960 \\
\hline Percentage, \% & 32.6 & 53.11 & 13.84 & 0.47 & $100 \%$ & $*$ & $*$ \\
\hline Number of questions, total & 313 & 510 & 133 & 5 & 960 & $*$ & \\
\hline $\begin{array}{l}\text { The average number of test questions for } \\
\text { professional competence assessment }\end{array}$ & 10 & 17 & 4 & 1 & 32 & & \\
\hline
\end{tabular}

Table 3. Test example codifier of an enterprise competence assessment (Business and tax accounting).

\begin{tabular}{|c|c|c|c|c|c|}
\hline 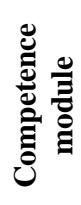 & 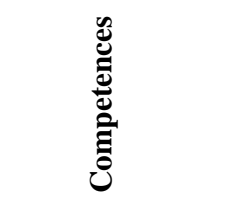 & 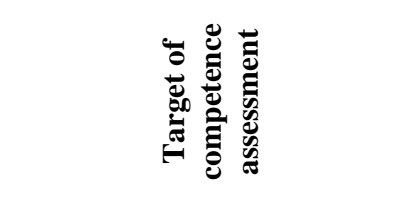 & 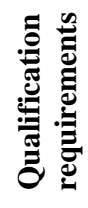 & 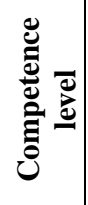 & 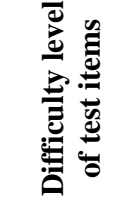 \\
\hline \multirow[t]{2}{*}{ 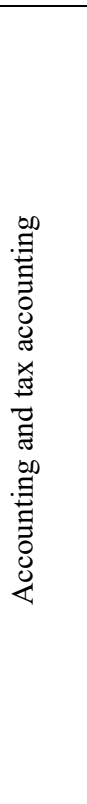 } & \multirow{2}{*}{$\begin{array}{l}1.2 \\
\text { Methodology } \\
\text { and regulations } \\
\text { (RAS - Russian } \\
\text { Accounting } \\
\text { Standards) } \\
\text { Knows the } \\
\text { methodology } \\
\text { and regulations } \\
\text { (RAS) } \\
\text { governing the } \\
\text { Russian } \\
\text { enterprises } \\
\text { accounting; } \\
\text { (Civil Code of } \\
\text { the Russian } \\
\text { Federation, } \\
\text { federal laws and } \\
\text { government, } \\
\text { regulations, the } \\
\text { Russian Finance } \\
\text { Ministry }\end{array}$} & $\begin{array}{l}\text { 1.1.1 Provides established law } \\
\text { and regulations compliance of } \\
\text { the Russian Federation in the } \\
\text { field of organization and record } \\
\text { keeping at the enterprise. }\end{array}$ & $\begin{array}{l}0 \\
\frac{80}{0} \\
\frac{0}{3} \\
0 \\
0 \\
1\end{array}$ & \multirow[t]{2}{*}{1} & \multirow[t]{2}{*}{ beginning } \\
\hline & & $\begin{array}{l}\text { 1.1.2 Possesses skills of } \\
\text { application of the Russian } \\
\text { Accounting } \\
\text { guidelines, regulations and } \\
\text { corporate accounting policy. }\end{array}$ & 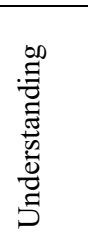 & & \\
\hline
\end{tabular}




\begin{tabular}{|c|c|c|c|c|}
\hline \multirow[t]{8}{*}{$\begin{array}{l}\text { accounting } \\
\text { regulations; } \\
\text { sectoral and } \\
\text { professional } \\
\text { associations' } \\
\text { recommendation } \\
\text { s). }\end{array}$} & $\begin{array}{l}\text { 1.1.3 Enhances profound } \\
\text { knowledge of Russian } \\
\text { Statutory Accounting to one } \\
\text { specific type of work; } \\
\text { distinguishes tax, regulatory } \\
\text { and financial accounting. }\end{array}$ & $\begin{array}{l}\frac{8}{00} \\
\frac{0}{3} \\
0 \\
0 \\
0\end{array}$ & \multirow{4}{*}{2} & \multirow{4}{*}{ user } \\
\hline & $\begin{array}{l}\text { 1.1.4 Applies the Russian } \\
\text { Federation laws and } \\
\text { regulations in view of } \\
\text { amendments and } \\
\text { modifications in the field of } \\
\text { accounting. }\end{array}$ & 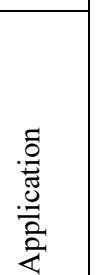 & & \\
\hline & $\begin{array}{l}\text { 1.1.5 Selects the oil and } \\
\text { gas industry accounting } \\
\text { process to improve the } \\
\text { corporate accounting policy } \\
\text { for one specific type of work }\end{array}$ & 告 & & \\
\hline & $\begin{array}{l}\text { 1.1.6 Assists other colleagues } \\
\text { or checks the accounting } \\
\text { transaction implementation. }\end{array}$ & 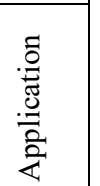 & & \\
\hline & $\begin{array}{l}\text { 1.1.7 Possesses approach and } \\
\text { technology accounting process } \\
\text { knowledge of different types } \\
\text { of accounting. }\end{array}$ & 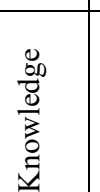 & \multirow{4}{*}{3} & \multirow{4}{*}{$\begin{array}{c}\text { experienc } \\
\text { ed }\end{array}$} \\
\hline & $\begin{array}{l}\text { 1.1.8 Understands accounting } \\
\text { process relationships in } \\
\text { package, as well as at the } \\
\text { detailed description level. }\end{array}$ & 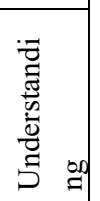 & & \\
\hline & $\begin{array}{l}\text { 1.1.9 Understands and answers } \\
\text { the complex and specific } \\
\text { questions concerning } \\
\text { methodology, accounting; } \\
\text { solves accounting organization } \\
\text { issues }\end{array}$ & $\frac{\sqrt[n]{n}}{\stackrel{\frac{\pi}{\pi}}{\frac{1}{4}}}$ & & \\
\hline & $\begin{array}{l}\text { 1.1.10 Forms corporate } \\
\text { accounting policy, taking into } \\
\text { account the subsidiaries } \\
\text { peculiarities; understands the } \\
\text { particular accounting policy of } \\
\text { OJSC "Gazprom Neft"; } \\
\text { understands the accounting and } \\
\text { financial reporting relationship }\end{array}$ & $\frac{n}{n}$ & & \\
\hline
\end{tabular}


Table 4. General test structure for Chief Accountant, Project manager of close and formation accounting statements.

\begin{tabular}{|c|c|c|c|c|c|}
\hline \multicolumn{2}{|c|}{$\begin{array}{c}\text { Department of close and formation of financial } \\
\text { statements }\end{array}$} & \multirow{3}{*}{ 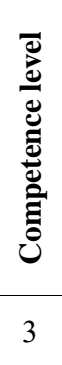 } & \multirow{3}{*}{ 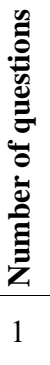 } & \multirow{3}{*}{ 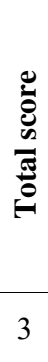 } & \multirow{2}{*}{ 晜 } \\
\hline \multicolumn{2}{|r|}{ Chief Accountant, Project Manager } & & & & \\
\hline \multirow{4}{*}{$\begin{array}{l}\text { Accounting } \\
\text { and tax } \\
\text { records }\end{array}$} & $\begin{array}{l}\text { 1. General principles, elements and types of } \\
\text { accounting }\end{array}$ & & & & \multirow{29}{*}{$\begin{array}{l}120 \\
\min .\end{array}$} \\
\hline & 2. Methodology and regulations (RAS) & 3 & 1 & 3 & \\
\hline & 3. Tax legislation, maintaining tax records & 3 & 1 & 3 & \\
\hline & 4. IFRS accounting principles & 2 & 1 & 2 & \\
\hline \multirow{3}{*}{$\begin{array}{l}\text { Knowledge } \\
\text { of business } \\
\text { organization }\end{array}$} & $\begin{array}{l}\text { 5. Incorporation documents, policies and } \\
\text { procedures }\end{array}$ & 3 & 1 & 3 & \\
\hline & 6. Institutional environment & 3 & 1 & 3 & \\
\hline & 7. Business trends & 3 & 1 & 3 & \\
\hline \multirow{15}{*}{ Processes } & 8. RF Accounting and Reporting & 3 & 2 & 6 & \\
\hline & 9. Taxes & 2 & 1 & 2 & \\
\hline & 10. Purchase records & 2 & 1 & 2 & \\
\hline & 11. Sale records & 2 & 1 & 2 & \\
\hline & 12. Inventory count & 2 & 1 & 2 & \\
\hline & 13. Assets Accounting & 2 & 1 & 2 & \\
\hline & 14. Capital investment records & 2 & 1 & 2 & \\
\hline & 15. Investment accounts & 2 & 1 & 2 & \\
\hline & $\begin{array}{l}\text { 16. Accounting credit, loan and collateral for } \\
\text { obligations }\end{array}$ & 2 & 1 & 2 & \\
\hline & 17. Purchasing services & 2 & 1 & 2 & \\
\hline & 18. Rendering services & 2 & 1 & 2 & \\
\hline & 19. Accounting for banking transactions & 2 & 1 & 2 & \\
\hline & 20. Cost Accounting and value formation & 2 & 1 & 2 & \\
\hline & 21. Salary Accounting and Payroll & 2 & 4 & 8 & \\
\hline & 22. Employee advances & 2 & 1 & 2 & \\
\hline \multirow{5}{*}{ IT skills } & 23.SAP FI & 1 & 1 & 1 & \\
\hline & $24.1 \mathrm{C}$ & 1 & 2 & 2 & \\
\hline & 25. Electronic archive system & 1 & 1 & 1 & \\
\hline & 26.MS Office & 2 & 1 & 2 & \\
\hline & 27.Internet/Intranet & 2 & 1 & 2 & \\
\hline \multirow{2}{*}{$\begin{array}{l}\text { Competence } \\
\text { levels }\end{array}$} & 1 - beginning & 3 & 4 & 4 & \\
\hline & 2 - user & 17 & 20 & 40 & \\
\hline
\end{tabular}




\begin{tabular}{|c|c|c|c|c|c|}
\hline & 3 - experienced & 7 & 8 & 25 & \\
\cline { 1 - 5 } TOTAL & 27 & 32 & 69 & \\
\hline
\end{tabular}

According to the general competence profile, codifiers and specifications, test bank was developed (Table 2).

The results of such personnel testing are the following:

- description of the professional competence assessment stages and techniques;

- profile description of technical knowledge and skills required for positions, by codifiers and specifications for each company specialist;

-common test bank;

- professional competence assessment results via a testing method;

- knowledge and skills inventory of the petroleum specialists via the developed tests (especially after the restructuring);

- obtained data analysis of the technical strengths and weaknesses of the specialists and the enterprise,

- sustainable competitive ability of the enterprise and its subdivisions within this or that sector;

- follow-up revision of the personnel assessment results;

- program development of advanced professional training reflecting obtained analysis results (optimized training programs planning; feedback; job position requirements).

- motivation in personal development and career growth.

It is worth noting that such an approach is effectively being used in several petroleum companies: employee performance efficiency mechanism, as well as testing (preliminary and post professional training); growth dynamics [6].

\section{Conclusion}

This competence assessment algorithm is of great importance, both for Personnel Development Department officers and for any employee who is responsible for decisionmaking in the HR Policy, as well as for personal and career development. The results of the tests will affect the production optimization and operation of the company itself.

\section{References}

1. R. Pillai, An empirical study on the role of HR practices in knowledge sharing with special reference to IT / ITeS firms, International Journal of Applied Engineering Research, 11(6), 3814-3818 (2016)

2. V.I. Baydenko, Competence approach in design of the State Educational Standard of Higher Professional Education. Moscow 2005114 (2005) [in Russian]

3. N.S. Mihaylova, Development of test materials (Tomsk: Publishing house TPU, 2008) [in Russian]

4. N.S. Mihaylova, M.G. Minin, E.A. Muratova, Assessment tools development in educational programs design (Tomsk: TPU, 2007)

5. M.P. Lyubyatinskaya, V.B. Romanyuk, Tools of knowledge and skills estimation of accounting and economic services of oil and gas companies, Siberian financial school, 6(83), 122-125 (2010) 
6. V.B. Romanyuk et al., Systematic approach in petroleum personnel competence assessment, IOP Conference Series: Earth and Environmental Science, 43, 012090 (2016) 